\title{
FACTS AND COMMENTS
}

Photographic Surveying. Robert H. Merrill . . . . . . 343

Supplementary Data on Early Man in America. Hans E. FischeL . 346

\section{BOOK REVIEWS}

Lillakd, Heizer and Fenenga: An Introduction to the Archaeology of Central California; HeIzer and Fenenga: Archaeological Horizons in Central California (Drucker).

Mason: Archaeology of Santa Marta, Colombia. The Tairona Culture; Part II, Section 2, Objects of Pottery (Kidder, II) . 363

Rouse: Prehistory in Haiti; A Study in Method. (Lothrop) . . 364

Colton: Prehistoric Culture Units and Their Relationships in Northern Arizona (Steward) . . . . . . . . . . . 366

Mera: Population Changes in the Rio Grande Glaze-Paint Area. (White)

ELLIS: Flint-Working Techniques of the American Indians: An Experimental Study (Movius) . . . . . . . . . 369

McCown and Keith: The Stone Age of Mt. Carmel. II, The Fossil Remains from the Levalloiso-Mousterian (Krogman) . . 370

Rogers: Prehistoric Man of the Santa Barbara Coast (Heizer) . 372

WissLer: Indians of the United States (McKern) . . . . . 375

Martin: Archaeological Work in the Ackmen-Lowry Area Southwestern Colorado: Modified Basket Maker Sites, AckmenLowry Area Southwestern Colorado (Morris) 
